\title{
The Role of Father in Character Building of Early Childhood in the Family Environment of Labour Women in Indonesia
}

\author{
Wilodati \\ Universitas Pendidikan Indonesia \\ Corresponding e-mail: wilodati@upi.edu
}

\begin{abstract}
Childhood is the most important part in a person's life because that is when the parents in the family are obliged to build noble character values that will be the basis of his personality in days to come. Education at an early age the child receives is the foundation of his noble character in the future. The parenting system who applied by parents is closely related to the character of the child in the future. Generally, parenting is done jointly and continuously by both parents. This was not the case in the family environment of Labor Women, where women who work as foreign workers must leave the house within a certain time. Automatically, when the mother is not there, childcare responsibilities entirely switched to the father. This research aims to get an overview about the fathers parenting on early childhood in the family environment of Labor Women. In order to describe the social situation in depth, then used a qualitative approach. The father and his sons is a participant in the study. Data collection techniques, through observation; deep interview; and literature studies. Data analysis include data reduction, data display, and conclusion. Triangulation of data sources, which is one component of testing the credibility of the data in qualitative research, also conducted. The results showed, the typology of parenting fathers tend to do is authoritative. The methods used in the construction of the children's character at an early age is imitation and conditioning. A typology of different father parenting, it turns out that tend to produce different characters within the child
\end{abstract}

Key words: The character of early childhood, Labor women family, Father parenting

\section{INTRODUCTION}

Family is the first and principal environment in a child's life. Parenting is defined as the process of interaction between parents and children, which among other things aims to foster children's character, should be done by both parents together since the early age of children.

The toddler was the golden era in the life of a child. Parenting did right by both parents from early age children, believed to be an important influence on a child's personality.

In Indonesia, the general care of a child in the family environment is predominantly carried out by the mother. As reflected in the opinion Supartiningsih (2003) "Traditional gender division of labor (gender division of labor base) place the division of labor, women in the home (domestic sector) and men working outside the home (the public sector)."
The monetary crisis in 1997 , led to the need to double the income of each family. It is then pushed partially out of housewives in Indonesia to earn a living outside the home, and even abroad, such as women workers to Saudi Arabia, not least also in Karawang, Kutawaluya regency Sindangmulya District of West Java province of Indonesia.

The position of mothers who work abroad within a minimum period of two years, automatically makes her role as a nanny in a family environment switch entirely to the father. The process of child care in the family environment must not be interrupted by the departure of the mother for a while. A character building early childhood without a mother still had to take place within a certain time. This study seeks to provide an overview parenting foster father in early childhood characters in the family environment Labor Women, which is the focus of this study. 


\section{LITERATURE REVIEW}

The main purpose of child care in the family environment is to Habituation noble character against themselves. Therefore, parenting needs to be done properly by parents, since children early age. This is consistent with the statement of the Harvard Family Research Project (2006) as follows:

Parenting is the family involvement process that includes the attitudes, values, and practices of parents in raising young children. Nurturing, warm, and responsive parent-child relationships and parental participation in child-centered activities relate to positive learning outcomes in early childhood.

The effectiveness of parenting style by considering two dimension of parenting, as depicted in Figure 1 (Joseph \& John, 2008) :

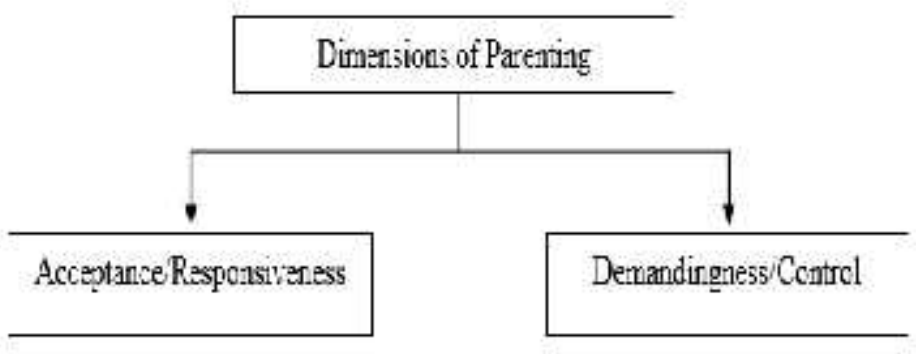

Figure 1. Dimensions of Parenting

Parental acceptance/responsiveness (also referred to as parental warmth or supportiveness) refers to "the extent to which parents intentionally foster individuality, self-regulation, and selfassertion by being attuned, supportive, and acquiescent to children's special needs and demands". Parental demandingness (also referred to as behavioral control) refers to "the claims parents make on children to become integrated into the family whole, by their maturity demands, supervision, disciplinary efforts and willingness to confront the child who disobeys" (Joseph \& John, 2008).

Furthermore, in his pioneering research Baum rind identified three parenting styles as follows (Mensah \& Kuranchie, 2013):

The authoritative style balances clear, high expectations with emotional support and recognition of children's autonomy. The authoritative parent tries to direct the child, but in a rational manner. The authoritative parent tries to direct the child, but in a rational manner.
Such a parent encourages give and take but shares the reasoning behind his or her rules. These parents value both autonomous self-will and disciplined conformity. They exercise firm control with certain points but the child is not tied up with restrictions

The authoritarian parent tries to shape, control, and evaluate the behaviour and attitudes of the child in accordance with a set standard of conduct. The permissive parent attempts to behave in a nonpunitive, accepting, and affirmative manner towards the child's impulses, desires, and actions. With this type of parenting, few demands are made of the child regarding such things as chores. This type of parenting does not require the parent to act as an active agent responsible for shaping or altering the child's behaviour.

Type of parental care to their children tend to vary, and it is believed experience influence on the character of their children.

The character is an attitude that is reflected in the said, and the person's behavior, which is part of his personality that is unique, and can be the difference between the person with another person (Wilodati et.al., 2016).

Development of an individual of good character should be done as early as possible, in all spheres of life of the individual, ranging from families, schools, and communities. A good character must be preceded by a process of character education is good too.

Ratna Megawangi (Syarbini, 2013) stated that 'The character education is an effort to educate children to make decisions wisely and put it into practice in daily life so that they can make a positive contribution to the environment '.

Special about character education in early childhood, Ratna Megawangi in Andrianto (2011), argued as follows:

Character education, including in the area of formal, informal and non-formal, at a very early age children, need an example as modelling and habituation in everyday life as a habit. Character education in early childhood is given in ways appropriate to the child's condition, such as playing, storytelling, conversation, and a real experience.

In connection with it, Sunaryo Kartadinata (Aunillah, 2011) states the following:

... of character education is a lifelong education at the same time the process of development toward a human. Therefore, requires an exemplary character education, from childhood 
to adulthood. In this case, the most sensitive and decisive are that education in the family that is the responsibility of parents. Parenting really is one factor that significantly helped shape the character of the child.

It can be concluded, the habituation of character must be done through the parents' parenting right from an early age children, so children can form noble character in days to come.

\section{METHOD}

This study intends to know parenting fathers in early childhood character builder in the family environment of women workers in the village Sindangmulya Kutawaluya District of Karawang district, West Java Indonesia. To get an idea of the social phenomena in depth is used a qualitative approach, which is expected to describe the social situation in the right way, based on the techniques of collecting and analysing relevant data.

This research subject is a family of migrant workers that are the focus of this study. Two primary data source used in this study is the respondent (husband whose wife become migrant workers, as well as their children); and informants base is the village chief, village officials, as well as RW and RT where respondents live); and the principal informant, those relative are involved in the care of children in the family environment of the migrant workers. Secondary data were obtained from various sources, both governmental and nongovernmental, ranging from a village, sub-district to a district, published or unpublished. The location of this research is a family Labor Women in the village Sindangmulya District of Kutawaluya, Karawang, West Java, Indonesia

Data collection techniques used in this study was the observation; interview; and documentation. In order to collect data in this study, also conducted triangulation technique, which the researchers tried to combine all three sources of data in this study is the father; child; and relatives are involved in the care of children in the family of the migrant workers. Triangulation is once again intended as well as testing the validity of the data, in particular, the credibility of the data, so that the data obtained is consistent, thorough, and definitely

Form of triangulation that researchers do is reflected in the following picture:

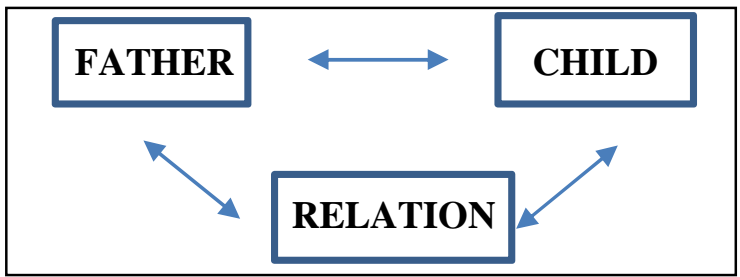

Figure 3-1 Triangulasi Data Source

The technique of data analysis refers to the qualitative data analysis techniques, which consists of three flow of activities that occur simultaneously, namely, "Data reduction, data presentation, drawing conclusions / verification".

\section{RESULT}

Based on observations and interviews conducted, it can be stated that there are three different typologies of parenting father in the family of the migrant workers, namely (Wilodati et.al., 2016):

1. The first parenting, with characteristics such as:

Father giving freedom with certain limitations while parenting. Parenting with great affection, warmth, tenderness, and familiarity. The contract for harmonious communication between father and children. Father give the opportunity to the children to develop his independence.

2. The second parenting, with characteristics such as

While caring for children, a father giving freedom to children in attitude and behavior. Father very involved in the child's life; never demanded anything against children, and never did controlcontrol when caring for children. When children make mistakes, never punishing. All the desire and willingness of the child always obeyed.

3. The third parenting, with characteristics such as:

The child must comply with all rules set by the father, do not provide opportunities for children to ask the rules are applied. When a child in violation of existing regulations, father warned explicitly, even punished him physically. Father decide all decisions related to the needs of children.

Baumrind identified three styles: authoritative, authoritarian, and permissive with these concepts of responsiveness and demandingness in mind (Bibi et.al, 2013) is as follows:

The authoritative parent is a combination of demandingness and responsiveness. They make logical demands, set limits and insist on children's complacent whereas at the same time, 
they are warm, accept the children's points of view and encore age the children's participation in decision making and often seek their children's views in family considerations and decisions.

The authoritarian parenting style is demanding and unresponsive. They engage in little mutual interaction with the children and expect them to accept adult's demands without any questions. Permissive parenting exposes an overly tolerant approach for socialization with responsive and undemanding parenting behavior. These parents are nurturing and accepting, but at the same time, they avoid imposing demands and controls over child's behavior

Referring to the Baumrind opinion, based on their characteristic parenting unity belongs to the type of authoritative parenting. Fathers caring for children with certain restrictions; attentive and affectionate; in harmonious communication fabric.

Furthermore, parenting both of the above results, including to the type of permissive parenting. This is evident from the attitude of the father who never requires children to obey the rules set forth. Dad seemed to let the child follow what they want. According to the father, the wishes of children must always be obeyed. Dad never controls the child. Supervision is done, but it evolved over time.

Meanwhile, the third parenting can be categorized into the type of authoritarian parenting. Since the beginning of the father has set rules that must be implemented in everyday life. Dad did strict control when caring for children. The child is conditioned to be able to take care of all of its requirements itself, and not rely on others.

Based on the results it can be stated that the trend of the type of care used by the father to be the focus of this study is authoritative.

Furthermore, the method used by the father to build the character of his children is imitation and habituation. In an effort to instil a number of character values in the child, the father makes himself as an example, by first doing the character values in everyday life, with the hope that his son would follow the example of some of the embedded value of the character.

Imitation is the main thing to do parents in growing efforts of character values in the child. This is in accordance with the opinion of Syarbini (2013) the following: "Psychologically, children are in desperate need of a role model or example in the family. So with the example of a child can apply in everyday life ".

The next method is carried out when the father habituating character values in their children. So, after the father exemplified the values of these characters, followed by habituation implementation of character values in the lives of children daily. According to my father, everything is already accustomed since childhood, will imitate in the child and will be done voluntarily without being forced by anyone.

The importance of character building of children from an early age through habituation method, proposed by Al-Ghazali in Syarbini (2013) the following:

Child's heart like a paper that was not scratched at all by writing or drawing. But he can accept any form of writing that is inscribed, or what is depicted in it. In fact, it will tend to something that is given to him. That trend will eventually become a habit and finally to the trust (personality). Therefore, if the child is accustomed to doing things well from childhood, then it will grow in goodness, and the impact it will survive in this world and hereafter.

Furthermore, each type of parenting that father used, it appears the image of the characters of her children as follows (Wilodati et. al., 2016):

Character produced by the father of Authoritative parenting is as follows: Easy to get along with anyone; Grow as a communicative and adaptive child; Appears as an independent child and have the highest confidence. The character generated by the user's father Permissive parenting is as follows: must constantly be obeyed her wishes; his behavior somewhat unruly / controlled, wants to behave as they please; are less able to socialize with people; difficult to associate. The character generated by the user's father Authoritarian parenting is as follows: Less responsible; often behave aggressively, especially if his wishes were not obeyed; less good at communicating with others; the child is not conforming, often seen as a rebellious son, and like to rebut parent command difficult to forgive the mistakes of others; like it wants to win its own (selfish), all his wishes must be quickly met; seeking attention by way of a sulk and denied counsel parents; tend to withdraw from the Association .

Based on the results of research conducted in the migrant family can be stated, that the father of the different typologies of parenting can produce different characters in the child. 


\section{CONCLUSION}

Child care in a family environment with the primary aim to foster their characters is the obligation of both parents and should be done on an ongoing basis. Absence mother for a certain period because he was working abroad, automatically makes parenting responsibility is transferred to the father.

The toddler was the golden era in the life of a person, must be filled with coaching a number of noble character values that will be the basis of his personality. Father proper parenting while caring for children at an early age, along with methods of imitation and habituation in their character building, believed to be able to frame the child's personality with a noble character in him.

In further research, it seems necessary to do a study of the influence of parenting typology father in the family environment of women workers, in an effort to make them self-sufficient children.

\section{REFERENCES}

Andrianto, T.T. (2011). Mengembangkan Karakter Sukses Anak di Era Cyber.Jogjakarta: Ar-Ruzz Media, p. 93

Aunillah, N.I. (2011). Panduan Menerapkan Pendidikan karakter di Sekolah. Yogyakarta: Laksana, p. 143-148

Bibi et.al. (2013). Contribution of Parenting Style in Life Domain of Children. IOSR Journal Of Humanities And Social Science (IOSR-JHSS). Volume 12, Issue 2 (May. - Jun. 2013), PP 9195

Harvard Family Research Project. (2006). Family Involvement in Early Childhood Education. No. I in A Series: Spring, p.1-8

Joseph M. V. \& John J. (2008). Impact of Parenting Styles on Child Development. Global Academic Society Journal: Social Science Insight, Vol. 1, No. 5, pp. 16-25.

Mensah, M.K. \& Kuranchie, A. (2013). Influence of Parenting Styles on the Social Development of Children. Academic Journal of Interdisciplinary Studies. Rome-Italy: MCSER Publishing. Vol 2 No 3 November 2013, p.123-129

Supartiningsih. (2003). Peran Ganda perempuan Sebuah Analisis Filosofis Kritis, Jurnal Filsafat, April 2003, Jilid 33, Nomor 1, Universitas Gajah Mada Yogyakarta, p.43

Syarbini, A. (2013). Model Pendidikan karakter dalam Keluarga Revitalisasi Peran Keluarga dalam Membentuk Karakter Anak Menurut
Perspektif Islam. Jakarta: PT. Elek Media Komputindo, p.61-62

Wilodati et.al. 2016. A Typology of FatherParenting in The Migrant Workers Family and Effect on Character of Children: Atlantis Press, p.223227 